\title{
RISK MANAGEMENT IN THE DECISION MAKING PROCESS CONCERNING THE USE OF OUTSOURCING SERVICES IN THE BULGARIAN ARMED FORCES
}

\author{
Nikolay NICHEV \\ "Vasil Levski" National Military University, Veliko Tarnovo, Bulgaria \\ nbnichev@nvu.bg
}

\begin{abstract}
Outsourcing services in the armed forces are a promising tool for reducing defence spending which use shall be determined by previously made accurate analysis of peacetime and wartime tasks of army structures. The decision to implement such services allows formations of Bulgarian Army to focus on the implementation of specific tasks related to their combat training.

Outsourcing is a successful practice which is applied both in the armies of the member states of NATO and in the Bulgarian Army. Using specialized companies to provide certain services in formations provides a reduction in defence spending, access to technology and skills in terms of financial shortage.

The aim of this paper is to analyse main outsourcing risks that affect the relationship between the military formation of the Bulgarian army, the structures of the Ministry of Defence of the Republic of Bulgaria and service providers, and to assess those risks. The basic steps for risk management in outsourcing activities are determined on this base.
\end{abstract}

\section{Keywords: outsourcing, risk management, outsourcing risk}

\section{Introduction}

Outsourcing is an effective tool to generate new revenue, and the risks that may arise, draw our attention to identifying the main types of outsourcing risks. This requires the focus of current research on studying and evaluating the possibility of the occurrence of such risks, and the development of a system for risks management on this basis. In accordance with this, it becomes necessary for the Bulgarian Armed Forces and the structures of the Ministry of Defence of the Republic of Bulgaria to retain control of their own key functions in the public sector of defence.

According to the guidance documents of the Ministry of Defence, risk is the possibility of the occurrence of an event which will affect the achievement of the adopted (planned) objectives of the structure [2,8].
It is measured by its impact and the probability of occurrence, and its management is the process of identifying, analysing, evaluating, monitoring, countering and reporting the risks that may affect the achievement of the objectives of an organisation and the implementation of the necessary control activities in order to limit the risks to an acceptable level.

Risk management in the Ministry of Defence of the Republic of Bulgaria is a dynamic process which should provide a better understanding of potential threats, actions or events that may positively or negatively affect the ability of the military structure to achieve its objectives and planned activities. It is a mandatory part of management of defence and its resources, and a key activity which contributes to the achievement of set goals. 


\section{Types of Outsourcing Risks}

Studies show that the most frequently observed risks are those when the outsourcing provider does not offer the expected and pledged quality of the service to military units. Experience shows that immediately after outsourcing, the service reduces its quality in comparison with previously offered services in the organisation [3, 4]. To overcome this risk, an adjustment period of about a year and a half should be planned, during which the supplier is able to get to know the process and the customer requirements. It can be expected that the quality of the outsourced service will increase after the specified period. This requires finding the appropriate external contractor.

It is noteworthy that before the transfer of the service to an external supplier, the achievement of the required quality of the activity is a responsibility of the personnel of the designated military unit - the client. After making the decision to use outsourcing, the management of the military unit should rely on the conditions laid down in the contract and ensure that the external provider adheres to them. To ensure this, guarantee measures should be co-ordinated and bound to the current national quality certificates [9]. Giving orders for inspections at regular intervals is another measure to prevent such kinds of risks.

Along with the quality problem, hidden costs may sometimes occur. To avoid this, the financial parameters in the outsourcing contract related to the appropriate level of service should be clearly established, and the text must specify that there will be no additional costs for the customer except the indicated ones [4].

The personal interviews with servicemen from different units show that there is an opportunity for risk caused by inadequate performance of the contractor when activities or services are outsourced from the armed forces. The basic marks for the appearance of this disadvantage most often are factors such as poorly composed contract, scarce supply markets, and specificity and variability of the assets.

Outsourcing risks which should not be underestimated are belittling the main activities and reducing competence. These are risks which occur when the governing bodies of military units do not pinpoint its core activities, i.e. fail in properly distinguishing major from minor activities in the military unit. The refining of peacetime and wartime tasks has particular importance. The transfer of certain activities or services to external contractors puts the units of the Bulgarian Armed Forces at the risk of having limited control over the planning of these services. Therefore, the need of conducting more frequent meetings with the contractor occurs so that the military units are not in isolation from the outsourced services $[5,6,10]$.

Another problem for the structures of the armed forces in the use of outsourcing services may occur in the misuse of classified information under the Law on protection of classified information. To prevent such a threat, it is appropriate to take measures at the conclusion of the contract for transfer of services. Concluding an agreement for non-disclosure of information (a non-disclosure agreement, NDA) may be pointed as a preventive measure.

The decision to use outsourcing services in the Bulgarian Armed Forces can create risks for specific activities of the various units arising from making wrong decisions to reducing the level of service because of the worse quality of provided services. This is the reason why the foreign experience and mistakes should be examined before making a decision to use outsourcing in the Bulgarian Armed Forces and the specific activity of the military unit, which does services transfer, should be taken into account. Outsourcing in military structures contains specific risk of corruption. According to Terziev, Nichev and Bankov, the corruption encourages state officials to create new rules and delays in procedures. 
Corruption leads to decreased compliance with environmental, nutritional and other standards, reduces the quality of provided services and increases budget costs [11]. All the above mentioned requires military units to develop and implement a system of ongoing monitoring of the entire outsourcing process.

A great deal of the outsourcing agreements depend on the access to internet, the connectivity and the need for adequate infrastructure, which suggests that there may be an IT risk as well.

The best practices and the analysis of the studied literature suggest that the risks arising from incorrect or formal implementation of outsourcing in the structures of the Bulgarian Armed Forces are the following: loss of direct control and supervision of the transferred services; information leak; negative quality caused by the pressure of reduced deadlines; inadequate technology and financial resources for fulfilling the obligations; increase in the price because of the fact that upon signing the contract the service price does not include its continuous improvements; bankruptcy of the contractor; breach of confidentiality and security of the military unit; occurrence of unexpected costs; non-compliance and failure to comply with contractual rights and obligations; violation of other activities at the military unit; lack of opportunity for professional development $[5,6,7,10]$.

The analysis of the studied literature leads to the identification of the factors generating risks in the course of cooperation between a military structure and external contractors (Table 1) [7].

Table 1. Factors associated with the formation of risks arising in the course of cooperation between military units and external contractors

\begin{tabular}{|l|c|}
\hline \multicolumn{1}{|c|}{ Groups of factors } & \multicolumn{1}{c|}{ Features } \\
\hline Legal factors & $\begin{array}{c}\text { Risks due to changes in the regulatory framework and } \\
\text { levels of quality of outsourcing services. }\end{array}$ \\
\hline $\begin{array}{l}\text { Military and economic } \\
\text { factors }\end{array}$ & $\begin{array}{l}\text { Risks that depend on outsourcing market development, } \\
\text { quality selection of external contractor, validity of the } \\
\text { contract, outsourcing operations quality control. } \\
\text { Corruption risks leading to increased outsourcing costs } \\
\text { and creation of unfavourable terms for military units. }\end{array}$ \\
\hline $\begin{array}{l}\text { Military-psychological } \\
\text { and social factors }\end{array}$ & $\begin{array}{l}\text { Risks associated with changes in the organisational } \\
\text { structure of the military unit as a result of the transfer of } \\
\text { services to external contractors. } \\
\text { Risks related to social tension which arises or increases } \\
\text { among the personnel of the given unit as a result of altered } \\
\text { job functions or redundancies in the official staff list. }\end{array}$ \\
\hline $\begin{array}{l}\text { Risk of improper use of information by both the } \\
\text { military unit and the contractor of outsourcing services. } \\
\text { Risks due to a lower level of command staff awareness } \\
\text { at military units about possible negative consequences of } \\
\text { outsourcing services. }\end{array}$ \\
\hline
\end{tabular}

All the risks that the transfer of services and activities to external entities may cause in the sphere of the armed forces can easily become more than the benefits. This can be avoided by a consistent approach to the assessment of criteria supporting the choice in using outsourcing services as well as by concluding precise contractual agreements. Another important activity to prevent the majority of these risks is the creation of an 
emergency plan which provides for termination of the outsourcing project and consequently returning the services provided by the external supplier back into the units.

Risk management of outsourcing services is a gradual process of identifying, evaluating, monitoring, and control, as well as developing and implementing measures aimed at reducing the negative impact of these risks on the activities in the military unit. Risk analysis has a significant impact on the successful development of the outsourcing process. Considering the complexity and importance of identification and management of outsourcing risks, the personnel of the military unit involved in the outsourcing process must have the necessary skills and knowledge to evaluate the impact of this process on the overall activity of the unit by using appropriate methods, such as analogy, expert methods, analytical methods, etc.

\section{Strategy for Managing the Risk of Outsourcing Activities}

The decision to conclude an outsourcing deal should define the risks which the respective structure of the Bulgarian Armed Forces can take, as well as the activities which it should perform, in order to limit and avoid diversification. To do this, it is appropriate to form a strategy for managing the risk of outsourcing activities.

The main problem in forming the strategy is to determine the maximum level of risk that the military unit can assume, taking into account its specific activity, availability of resources and ability to neutralise the negative effects of risk situations in outsourcing [7]. Maximum risk level can be defined as the situation when the military unit exceeds its ability to offset expected losses caused by risky situations without deterioration of its combat readiness and financial potential. Therefore, in determining the amount of funds which the military unit as a client can use to cover any losses, it is necessary to take into account only the resources that are not used by it to carry out its main specific activities.

The expected risk level of the joint work of the unit as a client and the external provider is an indicator which depends on the intensity of the impact of related professional risks and probabilities for risk situations. It is characterised by the amount of damage and losses caused by the failure of the outsourcing process. Therefore, it is essential to provide for a certain amount of compensation actuated by a particular risk situation to offset possible losses. This element must be defined and included in the outsourcing contract.

In view of the above, the decision to outsource may be accepted if the expected risk level is less than the maximum level of risk.

The management of the outsourcing risk in the structures of the Bulgarian Armed Forces is an activity that requires a number of decisions related to identification, evaluation and control of the risk. A sample process for outsourcing risk management can be described by the following step model:

First step - identifying the risk factors for outsourcing by analysing the economic, social, legal and information-technological factors.

Second step - determining the expected level of risk based on potential losses from a risk situation, and assessing the probability for occurrence of risk situations. Third step - comparing the expected to the maximum outsourcing risk and making decisions about outsourcing of services and activities. If the expected level of risk is less than the maximum level of risk, the outsourcing proposal is accepted. If the expected level of risk is greater than the maximum level of risk, the outsourcing proposal must be rejected $[2,7]$.

The planning and implementation of decisions on the use of outsourcing in the structures of the Bulgarian Armed Forces should be based on the determination of the maximum amount of risk that can be taken, 
and compared with the expected level of risk in the cooperation with the external provider. The military unit - client will be able to act and make managerial decisions depending on the estimated amount of losses upon the occurrence of risk situations.

However, when one of the structures of the Bulgarian Armed Forces cannot afford to additionally recruit highly skilled and highly paid personnel for the performance of some services, then outsourcing is the only decision. The armed forces structures should aim at results with the highest quality of service, without risks and with lower costs.

The list of outsourcing risks remains open and may be supplemented depending on the individual characteristics and specificity of the various military units and structures which use outsourcing.

Military units can decide to use outsourcing for the purpose of increasing the effectiveness of outsourced services. However, the outsourcing process can have a negative effect on performance. This requires the evaluation of the appropriateness of using outsourcing services in the relation with the capabilities of the military unit and its specific activities. Outsourcing decisions should be flexible and in accordance with the security of information. The success of such a decision is indirectly linked to the performance of activities as: precise analysis; assessment of possible services which the military unit can provide for outsourcing; market research and research of companies providing outsourcing services; consistency in the selection of external providers, and last but not least the conclusion of precise outsourcing contract.

The effective implementation of outsourcing is associated with many risks that should be distributed between the armed forces and the private sector. Using the skills of the private sector changes the culture and develops the skills of the armed forces.

The main objectives in making the decision to outsource are not only improving the efficiency and effectiveness of the capabilities of military logistics, but also completing defence tasks by reducing the volume of activities and minimising costs.

The new economic realities of the beginning of the 21 st century tend to strengthen the trend of shifting the world economy based on domestic markets, interconnected by trade and investments, to an economy which encourages publicprivate partnerships. Globalisation as a progressive form of integration of nations is not only manifested in economic terms, but also in all spheres of cultural, political and social life. It is driven by new relationships between regions and countries in the new international policies, including governments, business and society [1]. Partnership at different levels leads to the creation of a new type of interaction, including in terms of defence and security.

\section{Conclusion}

Outsourcing in the armed forces, regardless of the risks involved in its use, is a perspective tool for reducing the cost of defence.

The analysis of outsourcing risks and the following decision to use outsourcing in the logistic support of the Armed Forces of the Republic of Bulgaria is in direct relation with the peacetime and wartime tasks of military units. Military units with a high degree of readiness should use their own logistic structures to provide the necessary resources just in time and place, with the necessary quality and at an acceptable price. The applicability of outsourcing in the Armed Forces of the Republic of Bulgaria allows commanders to focus on the implementation of specific tasks related to the combat training of military units. 


\section{References}

[1] Petrova, E., European Idunit and Social Partnership, Revista Academiei Fortelor Terestre, Romania, Sibiu, Vol. XVI, Nr. 3 (63) Trimestrul III, 2011, pp. $309 \div 315$.

[2] Bechev, Ivan at al., Strategy for Risk Management in Defence Programs of MoD Structures Directly Subordinate to the Minister of Defence and Armed Forces, Ministry of Defence of the Republic of Bulgaria, Sofia, 2015.

[3] Harizanova, M., Outsourcing: Role, Characteristics and Areas of Application, Research papers Vol. 2, University of National and World Economy, Publishing complex UNWE, Sofia, pp. 7-39, 2012.

[4] Slavova, M., Public-private Partnership in Bulgaria. Outsourcing Services. Handbook. Materials on Public-private Partnerships and Outsourcing, Chamber of Commerce Targovishte, C., 2009.

[5] Power, M., Kevin Desouza, Carlo Bonifazi, The Outsourcing Handbook. How to Implement a Successful Outsourcing Process, London, United Kingdom, p. 229 , 2006.

[6] Ministry of Finance of the Republic of Bulgaria, Methodological guidelines for publicprivate partnership, Sofia, 2009.

[7] Kostenko, P., Julia Minenkova, Natalia Karpova, Methods for Estimating the Risks of Outsourcing, Scientific methodically e-magazine 'Concept' №5, 2014. retrieved from http://cyberleninka.ru/article/n/sposoby-otsenivaniya-riskov-autsorsinga

[8] National Assembly of the Republic of Bulgaria, Program for Developing of Defence capabilities of the Armed Forces of the Republic of Bulgaria 2020 and the Headcount of the Armed Forces, Decision adopted by the National Assembly on 25.11.2015, published in the State Gazette №93, dated 01/12/2015.

[9] Dimitrova, S., N. Nichev, N. Stefanov, Development of Outsourcing Services, International Conference Knowledge-Based Organization, Volume 21, Issue 1, pp. 192197, 2015.

[10] Kostova, V., Outsourcing - Features and Perspectives, Scientific Almanac of The Free University of Varna, Issue 6, pp. 104-115, Varna, 2009.

[11] Terziev, V., N. Nichev, Stefcho Bankov, Corruption and National Security, International Scientific Journal "Innovation Research", №10, part 3, pp. 189-196, 2016. 